gevel” (s. 320). Om Hans Raun Iversen her spejler sig i Kaj Munk, skal jeg lade være usagt, men ikke desto mindre fornemmer man et vist teologisk slægtsskab mellem Kaj Munk og Hans Raun Iversen, når sidstnævnte betoner, at det, som Kaj Munk ville som teolog og præst, var at være medarbejder på Helligåndens projekt.

Til dette projekt hører for Hans Raun Iversen at gennemtænke og formulere en ny teologisk praksis for mission, diakoni og undervisning. I en artikel fra 1991 om kirkens mission i Tanzania refererer han derfor til de nødvendige erfaringer, som missionærerne gør sig som medarbejdere i den lutherske kirke. Han refererer specifikt til en artikel udarbejdet af Ida Kongsbak, der var teolog og underviser i kirken udsendt af Det danske Missionsselskab. Efter at have orienteret om udfordringerne i arbejdet henviser Ida Kongsbak til Kaj Munks prædikensamling Ved Babylons floder som en kilde til trøst og opmuntring, når det hedder: "At vidne om Gud det vil først og fremmest sige at leve sådan at livet bliver dyrebart for andre og det gode i dem styrkes." De ord var en kilde til opmuntring for Ida Kongsbak. De kan også stå som en overskrift for det stort anlagte praktisk teologiske projekt, Hans Raun Iversen bruger al sin tid på. Derfor tillykke med det hele.

Peter Lodberg

\title{
Encyclopedia of the Bible and Its Reception
}

Vol. 1: Aaron - Aniconism. Vol. 2: Anim - Atheism. Berlin - New York: de Gruyter 2009. Ill. s/h og farveplancher. Vol. 1: 1224 sp.; Vol. 2: 1208 sp. $€$ 238/\$325 pr. bind.

I et af sine essays anstiller Umberto Eco semiotiske overvejelser over landkort i størrelsesforholdet 1:1. Det randt mig i hu, da jeg modtog de første bind af $E B R$, for en encyklopædi om Bibelen og dens reception forekommer næsten at være en 1:1 optegnelse af den vestlige kulturhistorie. Værket er da også projekteret til i alt 30 bind, hvoraf det sidste planmæssigt skal udkomme i 2018. Udgivelsen er på mange måder en epokal begivenhed i bibelvidenskaben.

Overordnet har man inddelt området i fem hovedområder: Den hebræiske Bibel/Det Gamle Testamente, Det Nye Testamente, Jødedom, Kristendom og Receptionshistorie. Disse emner har hver deres hovedredaktør og er atter inddelt i fem-seks underområder med områderedaktører. Nils Holger Petersen fra Det Teologiske Fakultet i København er således områderedaktør for musik under hovedområdet receptionshistorie.

Værket vil blive en milepæl i bibelvidenskaben og som sådan vil det sige noget om, hvor forskningen befinder sig. Af den grund tiltrækker udgivelsen sig opmærksomhed som fænomen. Man kan ikke lade være med at spekulere på, hvilke tendenser i tiden projektet er udtryk for. Hvorfor lanceres værket netop nu, og hvorfor netop dette værk? En række interessante forhold springer i øjnene. For det første turde det nu være officielt, at engelsk er det fælles akademiske sprog også inden for bibelforskningen. For det andet er 
det nu uomgængeligt, at receptions- og virkningshistorie hører med til bibelvidenskaben. For det tredje er kristendommens selvfølgelige fortrinsret udfordret: Jødedom, kristendom og islam behandles side om side med andre religioner. Endelig for det fjerde er skellet mellem finkultur og populærkultur principielt ophævet: countrymusik optræder sammen med klassisk musik; tegnefilm behandles på lige fod med kunstfilm. Flere karakteristika som disse viser, at værket måske bedst kan anskues som bibelvidenskabens indtog i globaliseringens tidsalder.

Men hvad vil bibelvidenskaben i globaliseringen, kunne man spørge. Svaret kan naturligvis ikke leveres af denne encyklopædi alene, men den ser det tydeligvis som sin opgave at dokumentere bibelens næsten altomfattende indflydelse på den vestlige kultur og lejlighedsvise nedslag i andre kulturer. Spørgsmålet er, om det også er et tidstypisk træk. Mon ikke det netop er globaliseringen, hvor bibelens naturlige status som kulturens grundlag bestrides, der fremkalder behovet for at kortlægge dens betydning? Er encyklopædiens uudtalte og muligvis uerkendte, men meget tidstypiske anliggende at fremvise en ubrydelig forbindelse mellem vestlig kultur og den kristne bibel? I så fald kan projektet uforvarende bidrage til et identitetspolitisk anliggende ved at påpege det vestlige menneskes særtræk og dermed sætte skel mellem vesten og andre dele af den globaliserede verden.

Uanset hvilket tidstypiske motiver man måtte mene at kunne ane bag udgivelsesprojektet, er resultatet monumentalt. Det er et enestående og uvurderligt hjælpemiddel, som bibelforskere, kulturhistorikere, kunsthistorikere, litteraturhistorikere og alle andre nu får i hænde. Anvendelsesmulighederne er nærmest ubegrænsede. I overensstemmelse med de høje ambitioner er det på en og samme tid et almindeligt bibelleksikon med opslag om skrifter, personer, steder og historiske forhold (fx Apocalypses, Agrippa, Antioch og Arms-Bearer) og et forskningshistorisk opslagsværk med artikler om vigtige personer og retninger ( $f_{x}$ George A. Alt og Anthropological Approaches to the Bible), endvidere er det et kirke- og teologihistorisk leksikon om væsentlige personer, kirkelige retninger, teologiske forestillinger og begreber ( $\mathrm{fx}$ Apollinaris of Laodicea, Alogians, Apocatastasis og Abstinence), endelig er det et filosofi- og kulturhistorisk værk om markante kulturpersonligheder og strømninger (fx H.C. Andersen og Anti-Imperialism), foruden selvfølgelig en receptionshistorisk encyklopædi, der følger bibelske motiver i religions-, filosofi- og kunsthistorien ( $\mathrm{fx}$ Adam og Antichrist). Sjældent rummes så meget i et værk om bibelen.

I forhold til andre store leksika og encyklopædier er det navnlig det receptionshistoriske perspektiv, der adskiller fra $E B R$ fra forgængere som $R G G$ og $T R E$. En række almindelige teologi- og kirkehistoriske artikler er væsentlig kortere og mindre informative end de tilsvarende opslag i TRE. Omvendt er det modsatte oftest tilfældet i forhold til $R G G$. Men frem for alt behandles mange temaer og områder på en helt ny og nyskabende måde. Opslaget 
African Diaspora er et skoleeksempel på en artikel, man ikke finder magen til andetsteds. Den behandler kortfattet kristendommen i sub-Sahara, derefter afrikansk eksegese og teologi, så Islam i sub-Sahara og endelig bibelen i afrikansk litteratur og musik. Et andet eksempel på en sjov artikel er Alchemy. Her er det særligt inddragelsen af islamiske traditioner, der udmærker $E B R$. Et tredje eksempel på en enestående artikel er Aqedah. Særligt den yderst interessante og omfattende gennemgang af litteraturhistorien adskiller i den sammenhæng $E B R$ fra tilsvarende opslag i andre værker.

Er det i særlig grad den receptionshistoriske vinkel, der er det innovative islæt i $E B R$, er det også på det område, værket kan virke lidt usikkert. Vedrørende de gængse opslag har man kunnet støtte sig til andre leksika og derfor være sikker at nævne det væsentligste og ramme den gældende opfattelse. Det har man ikke kunnet angående receptionen. Receptionsbidragene er derfor i højere grad end andre leksikonartikler bestemt og begrænset af den enkelte forfatters horisont. Af den grund vil enhver læser sikkert undre sig over, at dette eller hint værk ikke er nævnt i receptionsartiklerne (fx filmen Apocalypse Now i artiklen Apocalypses, eller Harry Potter I: The Philosopher's Stone $\mathrm{i}$ artiklen Alchemy), men i det store hele er der grund til at have tillid til forfatterne.

Dette bringer mig til en sidste bemærkning, som også er et tidstypisk træk ved udgivelsen: Jeg har aldrig tidligere været i besiddelse af en smuk bogudgivelse og tænkt, at den kun er et biprodukt af online-udgaven. Det gør jeg med dette værk, for dets egentlige væsen må være elektronisk, ellers er de første bind forældede, inden de sidste udkommer. Kun i online-versionen kan artiklerne løbende updateres og holdes ajour med såvel forskning som kunst. Det er i denne fortsatte udvikling af værket, at dets virkelige værdi vil vise sig. Lykkes det forlaget også at varetage denne principielt uendelige opgave, vil EBR kunne blive et standardværk i dette århundrede.

Eftersom online-udgaven er den egentlige version af $E B R$, løses også et problem, som Umberto Eco anfører angående landkortet i størrelsesforholdet 1:1: Det kan være vanskeligt at opbevare! 